\title{
Peningkatan Komitmen Organisasi untuk Menurunkan Angka Turnover Karyawan
}

\section{Improvement of Organizational Commitment to Lower Employee Turnover}

\author{
Elita Halimsetiono
}

\author{
Departemen Administrasi dan Kebijakan Kesehatan Fakultas Kesehatan Masyarakat Universitas Airlangga
}

\begin{abstract}
Abstrak
Komitmen organisasi dapat diartikan sebagai suatu sikap yang harus dimiliki oleh setiap pegawai untuk menunjukkan loyalitas terhadap organisasi tempat mereka bekerja. Pada dasarnya, komitmen organisasi berkaitan erat dengan aspek-aspek psikologis dalam menerima dan memercayai nilai-nilai dan tujuan organisasi yang muncul sebagai keinginan untuk tetap mempertahankan keanggotaan dalam organisasi. Permasalahan yang sering dikaitkan dengan rendahnya komitmen organisasi adalah pindah kerja (turnover). Masalah ini memiliki dampak yang merugikan organisasi karena dapat menghambat efektivitas dan efisiensi kerja yang selanjutnya akan menurunkan tingkat produktivitas organisasi. Oleh karena itu, untuk mencegah tingginya turnover karyawan, organisasi perlu meningkatkan komitmen organisasi karyawannya. Caranya adalah dengan mengetahui faktorfaktor apa saja yang memengaruhi komitmen organisasi dan bagaimana cara untuk meningkatkan komitmen organisasi tersebut. Artikel ini membahas faktor-faktor apa saja yang memengaruhi komitmen organisasi dan cara-cara yang dapat digunakan untuk meningkatkan komitmen organisasi sebagai upaya untuk menurunkan angka turnover karyawan.
\end{abstract}

Kata kunci: Karyawan, komitmen organisasi, perpindahan kerja

\footnotetext{
Abstract

Organizational commitment can be interpreted as an attitude that should be owned by every employee to demonstrate loyalty to the organization where they work. Basically, organizational commitment is closely related to the psychological aspects in the acceptance and confidence to the values and objectives of the organization that are presented through the existence of a desire to maintain membership in the organization. Problems which are associated with low organizational commitment is turnover. This problem has an adverse impact on the organization because it can inhibit the effectiveness and efficiency of the work that would lower the level of productivity of the organization. Therefore, to prevent the high employee turnover, the organization should increase the organizational commitment of their em-
}

ployees. It can be done by identifying what factors influencing the organizational commitment of the employees and how to improve the employee's organizational commitment. This article discusses factors influencing the organizational commitment and ways that can be used to enhance the organizational commitment as efforts to lower the employee turnover rate. Keywords: Employees, organizational commitment, turnover

\section{Pendahuluan}

Perpindahan kerja (turnover) karyawan dapat mengganggu kelancaran pekerjaan di perusahaan atau organisasi. Apabila hal ini sering terjadi akan dapat mengganggu pencapaian tujuan perusahaan atau organisasi. Untuk mencapai tujuannya secara efektif, setiap perusahaan atau organisasi perlu mengelola sumber daya manusia (SDM) yang dimilikinya dengan sebaik-baiknya. Sumber daya yang potensial harus dipertahankan agar mereka loyal dan tidak pindah mencari pekerjaan yang lain sehingga kelangsungan dan perkembangan perusahaan pada masa yang akan datang dapat terjaga. ${ }^{1}$

Turnover karyawan merupakan hal yang tidak diinginkan perusahaan atau organisasi. Turnover biasanya merupakan salah satu pilihan terakhir bagi seorang karyawan apabila dia mendapati kondisi kerjanya sudah tidak sesuai lagi dengan apa yang diharapkannya. Untuk itu, perusahaan atau organisasi perlu menelaah lebih jauh tentang sebab-sebab seorang karyawan melakukan turnover sehingga dapat ditekan seminimal mungkin. Hal ini dapat dilakukan dengan cara mengatasi kendala-kendala

Alamat Korespondensi: Elita Halimsetiono, Departemen Administrasi dan Kebijakan Kesehatan FKM Universitas Airlangga, Kampus C Unair, Jl. Mulyorejo Surabaya 60115, Hp.085232074297,e-mail: elitahalims@yahoo.com 
yang menyebabkan seorang karyawan mempunyai niat untuk keluar, terutama sebab-sebab dari perusahaan atau organisasi itu sendiri. Salah satu variabel yang banyak diteliti dalam hubungannya dengan turnover adalah komitmen organisasi. ${ }^{2}$

Ada banyak alasan mengapa sebuah organisasi harus berusaha meningkatkan komitmen organisasi para karyawannya. Banyak penelitian menemukan bahwa semakin tinggi karyawan berkomitmen kepada perusahaan, karyawan tersebut akan berusaha lebih baik dalam menyelesaikan tugas-tugasnya. Selain itu, karyawan yang berkomitmen juga akan meningkatkan produktivitas kerjanya karena karyawan itu merasa menyatu dengan perusahaan dan bekerja untuk mencapai tujuan perusahaan. Dengan adanya rasa menyatu pada perusahaan, karyawan tidak akan berpikir untuk meninggalkan perusahaan, sehingga dikatakan bahwa komitmen organisasi yang tinggi akan menurunkan keinginan untuk pindah kerja para karyawannya.

Berdasarkan permasalahan yang telah diuraikan di atas, perusahaan dituntut memiliki suatu peranan penting dalam manajemen SDM. Perusahaan perlu mengatur SDM sebaik mungkin guna mencapai tujuannya secara efektif, yaitu dengan senantiasa melakukan investasi untuk penerimaan, penyeleksian, dan mempertahankan SDM yang potensial agar tidak berdampak pada perpindahan karyawan (turnover). Tulisan ini memaparkan permasalahan turnover yang berkaitan dengan komitmen organisasi.

\section{Turnover}

Turnover dapat diartikan sebagai keluarnya karyawan. Dalam arti luas, turnover diartikan sebagai aliran karyawan yang masuk dan keluar perusahaan. Namun turnover karyawan merupakan hal yang tidak bisa dihindari dan diharapkan oleh perusahaan. ${ }^{3}$ Turnover karyawan dikatakan normal apabila berkisar antara $5-10 \%$ per tahun dan dikatakan tinggi apabila lebih dari $10 \%$ per tahun. ${ }^{4}$

Turnover dapat dibedakan menjadi dua jenis, yaitu voluntary turnover dan involuntary turnover. Voluntary turnover adalah karyawan yang meninggalkan perusahaan karena alasan sukarela. Voluntary turnover dapat dibedakan menjadi dua, avoidable turnover (yang dapat dihindari) dan unavoidable turnover (yang tidak dapat dihindari). Avoidable turnover (yang dapat dihindari) disebabkan oleh upah yang lebih baik di tempat lain, kondisi kerja yang lebih baik di organisasi lain, masalah dengan kepemimpinan/administrasi yang ada, serta adanya organisasi lain yang lebih baik. Sedangkan unavoidable turnover (yang tidak dapat dihindari) disebabkan oleh pindah kerja ke daerah lain karena mengikuti pasangan, perubahan arah karier individu, harus tinggal di rumah untuk menjaga pasangan atau anak, dan kehamilan.
Involuntary turnover adalah karyawan yang meninggalkan perusahaan karena terpaksa. Involuntary turnover diakibatkan oleh tindakan pendisiplinan yang dilakukan oleh perusahaan atau karena lay off. ${ }^{5}$

Turnover bisa menimbulkan dampak yang negatif maupun positif bagi perusahaan. Salah satu dampak negatif yang utama dari turnover adalah biaya. Ada tiga komponen utama yang berhubungan dengan biaya yang disebabkan oleh turnover, yaitu biaya perekrutan karyawan baru, biaya yang harus dikeluarkan selama ada posisi yang kosong, dan biaya pelatihan. ${ }^{6}$

Selain biaya yang harus dibayar karena turnover, perusahaan juga memperoleh manfaat dari adanya turnover seperti pindahnya karyawan yang tidak produktif dan perbaikan dalam inovasi. Jika karyawan yang tidak produktif pindah dari perusahaan, perusahaan mempunyai kesempatan untuk mempekerjakan karyawan baru yang lebih produktif. Karyawan baru ini juga dapat memberikan ide baru dan kreatif serta membawa pengetahuan, keahlian, dan kemampuan mereka ke dalam perusahaan.

Angka turnover karyawan dapat diketahui dari jumlah karyawan yang masuk ke organisasi atau perusahaan (joining), jumlah karyawan yang keluar (leaving), jumlah karyawan pada awal tahun (starting employees), dan jumlah karyawan pada akhir tahun (ending employees). ${ }^{7}$ Rumus penghitungan dapat dilihat pada Rumus 1.

\section{Komitmen Organisasi}

Komitmen organisasi adalah derajat karyawan percaya dan menerima tujuan-tujuan organisasi dan akan tetap tinggal atau tidak akan meninggalkan organisasi. Komitmen organisasi merupakan dimensi perilaku penting yang dapat digunakan untuk menilai kecenderungan karyawan untuk bertahan sebagai anggota organisasi. Komitmen organisasi mencakup kebanggaan, kesetiaan, dan kemauan anggota pada organisasi. Komitmen organisasi didefinisikan sebagai suatu sikap yang merefleksikan perasaan suka atau tidak suka dari karyawan terhadap organisasi. ${ }^{8}$

Dalam komitmen organisasi, terdapat beberapa dimensi, meliputi komitmen afektif (affective commitment), komitmen berkelanjutan (continuence commitment), dan komitmen normatif (normative commitment). ${ }^{9}$ Komitmen afektif (affective commitment) mengacu pada hubungan emosional anggota terhadap organisasi. Orang-orang ingin terus bekerja untuk organisasi tersebut karena mereka sependapat dengan tujuan dan nilai dalam organisasi tersebut. Orang-orang dengan

Rumus 1. Penghitungan Angka Turnover Karyawan

Employee turnover rate $=\frac{(\text { Joining }+ \text { Leaving })}{(\text { Starting employee }+ \text { Ending employee })}$ 
tingkat komitmen afektif yang tinggi memiliki keinginan untuk tetap berada di organisasi karena mereka mendukung tujuan dari organisasi tersebut dan bersedia membantu untuk mencapai tujuan tersebut. Komitmen ini menyebabkan karyawan bertahan pada suatu pekerjaan karena mereka menginginkannya, atau dengan kata lain "stay because you want to". ${ }^{10}$

Komitmen berkelanjutan (continuence commitment) mengacu pada keinginan karyawan untuk tetap tinggal di organisasi tersebut karena adanya perhitungan atau analisis tentang untung dan rugi. Nilai ekonomi menyebabkan karyawan bertahan dalam suatu organisasi dibandingkan dengan meninggalkan organisasi tersebut. Semakin lama karyawan tinggal dengan organi-sasi mereka, semakin mereka takut kehilangan apa yang telah mereka investasikan di dalam organisasi selama ini. Artinya, komitmen kerja dianggap sebagai persepsi harga yang harus dibayar jika karyawan meninggalkan pekerjaannya, misalnya akan kehilangan senioritas atas promosi atau benefit. Komitmen ini menyebabkan karyawan bertahan pada suatu pekerjaan karena mereka membutuhkannya atau dengan kata lain "stay because you need to". 10

Komitmen normatif (normative commitment) mengacu pada perasaan karyawan yang mewajibkan mereka untuk tetap berada di organisasinya karena tekanan dari yang lain. Karyawan yang memiliki tingkat komitmen normatif yang tinggi akan sangat memperhatikan apa yang dikatakan orang lain tentang mereka jika mereka meninggalkan organisasi. Mereka tidak ingin mengecewakan atasan mereka dan khawatir jika rekan kerja mereka berpikir buruk terhadap mereka karena pengunduran diri tersebut. Komitmen ini menyebabkan karyawan bertahan pada suatu pekerjaan karena mereka merasa wajib untuk melakukannya serta didasari keyakinan tentang apa yang benar dan berkaitan dengan moral atau dengan kata lain "stay because you ought to". 10

Ada tiga aspek utama dalam komitmen organisasi, yaitu identifikasi, keterlibatan, dan loyalitas. ${ }^{11}$ Identifikasi adalah penerimaan dan kepercayaan pegawai yang kuat terhadap nilai-nilai dan tujuan organisasi. Karyawan yang mengidentifikasikan dirinya pada organisasi menilai adanya kongruensi antara nilai dan tujuan organisasi dengan nilai dan tujuan pribadinya. Akibatnya, pegawai akan rela menyumbangkan sesuatu bagi tercapainya tujuan organisasi karena dengan demikian secara tidak langsung kebutuhan atau tujuan pribadinya akan terpenuhi pula. Kepercayaan pegawai terhadap organisasi dapat ditumbuhkan dengan turut dirumuskannya kebutuhan dan harapan-harapan pegawai ke dalam tujuan organisasi sehingga pegawai dengan rela berusaha mencapai tujuan organisasi itu. ${ }^{12}$ Keterlibatan pekerjaan berhubungan dengan seberapa besarnya orang mengidentifikasi dan benar-benar peduli tentang pekerjaan yang mereka lakukan. Komitmen mengacu pada seberapa besar orang mengidentifikasi organisasi secara keseluruhan. Penelitian menunjukkan bahwa keterlibatan dan komitmen kerja yang tinggi berakibat pada rendahnya tingkat absensi dan turnover kerja. ${ }^{13}$

Keterlibatan atau partisipasi pegawai adalah kesediaan pegawai untuk berusaha sebaik mungkin demi kepentingan organisasi dengan melibatkan diri dalam aktivitasaktivitas kerja organisasi. Keterlibatan ini akan menyebabkan pegawai mau dan senang bekerja sama, baik dengan atasan maupun dengan sesama teman kerja. Keterlibatan pegawai dapat dirangsang dengan mengikutsertakan pegawai dalam pembuatan keputusan. Hal ini dapat membuat pegawai merasa diterima sebagai bagian dari organisasi dan menumbuhkan keyakinan bahwa apa yang telah diputuskan adalah merupakan keputusan bersama. Dengan cara itu, pegawai merasa bertanggung jawab untuk melaksanakan keputusan yang telah disepakati. ${ }^{14}$ Keterlibatan kerja dapat menyebabkan sikap positif dan perilaku yang mengarah pada motivasi yang tinggi seperti komitmen, inisiatif, dan tingkat kehadiran (misal rendahnya turnover dan tingkat absensi). ${ }^{15}$

Loyalitas atau kesetiaan terhadap organisasi adalah keinginan yang kuat untuk tetap menjadi anggota organisasi tempat ia bekerja. Karyawan akan mempertahankan keanggotaannya dalam organisasi karena karyawan merasa bahwa dirinya adalah bagian dari organisasi yang tidak terpisahkan. Hal ini dapat diupayakan bila karyawan merasa aman dan puas dalam organisasi tempat ia bergabung untuk bekerja. ${ }^{11}$

Ada dua faktor yang dapat memengaruhi komitmen karyawan terhadap organisasi, yaitu karakteristik pribadi dan pengalaman kerja. ${ }^{11}$ Faktor karaktersitik pribadi mencakup usia dan masa kerja, tingkat pendidikan, jenis kelamin, dan peran individu dalam organisasi. Sedangkan pengalaman kerja terdiri dari keterandalan organisasi, perasaan dianggap penting oleh organisasi, realisasi harapan individu, persepsi terhadap gaji, persepsi terhadap perilaku atasan, keadilan dan kepuasan kerja, keamanan kerja, pemahaman organisasi, keterlibatan karyawan, dan kepercayaan karyawan.

Karakteristik pribadi pada usia dan masa kerja berkorelasi positif dengan komitmen. Hasil studi menunjukkan bahwa salah satu prediktor terhadap komitmen adalah masa kerja (tenure) seseorang pada organisasi tertentu. Hal ini dapat dijelaskan dengan semakin lama seseorang bekerja pada suatu organisasi, semakin ia memberi peluang untuk menerima tugas yang lebih menantang, otonomi yang lebih besar, keleluasaan untuk bekerja, tingkat imbalan ekstrinsik yang lebih besar dan peluang mendapat promosi yang lebih tinggi. Adanya peluang investasi pribadi, yang berupa pikiran, tenaga dan waktu untuk organisasi yang makin besar membuat seseorang makin sulit untuk meninggalkan organisasi tersebut. Adanya 
keterlibatan sosial yang dalam dengan organisasi dan individu-individu yang ada, dan hubungan sosial yang lebih bermakna membuat individu semakin berat meninggalkan organisasi. Akses untuk mendapat informasi pekerjaan baru makin berkurang. ${ }^{16}$ Semakin tinggi tingkat pendidikan, semakin banyak pula harapan individu yang mungkin tidak bisa diakomodasi oleh organisasi sehingga komitmennya semakin rendah. ${ }^{16}$

Wanita pada umumnya menghadapi tantangan yang lebih besar dalam pencapaian kariernya sehingga komitmennya lebih tinggi. ${ }^{16} \mathrm{Hal}$ ini disebabkan pegawai wanita merasa bahwa tanggung jawab rumah tangganya ada di tangan suami mereka sehingga gaji atau upah yang diberikan oleh organisasi bukanlah sesuatu yang sangat penting bagi dirinya. ${ }^{17}$

Hasil studi menunjukkan bahwa adanya hubungan yang negatif antara peran yang tidak jelas dan komitmen terhadap organisasi. Peran yang tidak jelas muncul akibat adanya tujuan yang tidak jelas pula atas suatu pekerjaan. Ciri-cirinya antara lain ketidakjelasan evaluasi terhadap pekerjaan, cara untuk mencapai unjuk kerja yang baik, dan batas wewenang serta tanggung jawab individu. Ada beberapa faktor yang menyebabkan munculnya ketidakjelasan peran, yaitu faktor organisasi, keberadaan individu tidak jelas fungsinya sehingga peranannya pun tidak jelas, faktor pemberi peran, ketidakjelasan muncul karena atasan tidak mengomunikasikan dengan jelas harapannya terhadap bawahan, aktor penerima peran, ketidakjelasan peran karena bawahan tidak mengerti peran yang harus ia lakukan sesuai harapan atasan. ${ }^{16}$

Pengalaman kerja dan keterandalan organisasi menyatakan sejauh mana individu merasa bahwa organisasi tempat ia bekerja memperhatikan anggotanya, dalam hal minat maupun kesejahteraan. ${ }^{16}$ Jika organisasi dianggap dapat diandalkan dan peduli pada minat dan harapan anggota, dan harapan anggota turut dirumuskan dalam tujuan organisasi, individu akan merasa lebih bertanggung jawab dan ingin membalas jasa organisasi. ${ }^{12}$

Perasaan dianggap penting oleh organisasi menyatakan sejauh mana individu merasa diperlukan dalam mencapai misi organisasi. Tempat kerja yang baik adalah tempat yang membuat karyawan dihargai keberadaannya dan merasa bangga menjadi anggota organisasi tersebut. Ketidakberartian akan membuat komitmen organisasi menjadi rendah. ${ }^{16}$

Realisasi harapan Individu berarti sejauh mana harapan individu dapat direalisasikan melalui organisasi dimana ia bekerja. ${ }^{16}$ Apa yang diharapkan individu terhadap organisasinya akan memengaruhi sikap kerjanya. Bila organisasi memenuhi harapan individu, individu merasa pantas membalas jasa organisasi tersebut. ${ }^{12}$ Persepsi terhadap gaji menyatakan sejauh mana individu tersebut merasa gaji yang diterimanya seimbang dengan gaji indi- vidu lain. ${ }^{16}$

Persepsi terhadap perilaku atasan, berarti sejauh mana individu merasa dihargai dan dipercayai oleh atasan. Jika persepsi terhadap sikap atasan negatif, karyawan akan cenderung bersikap negatif pula yang diaktualkan dalam bentuk perilaku negatif, seperti mangkir dan keinginan berpindah kerja. ${ }^{16}$

Hal yang paling memengaruhi loyalitas karyawan adalah pengalaman kerja yang positif dan adil. Komitmen organisasi tampaknya sulit dicapai ketika karyawan menghadapi beban kerja yang meningkat di perusahaan tetapi profit yang didapatkan oleh perusahaan hanya dinikmati oleh manajer tingkat atas. Oleh karena itu, perusahaan dapat membangun komitmen organisasi dengan berbagi keuntungan yang diperoleh perusahaan kepada karyawannya. ${ }^{18}$ Kepuasan pembayaran sangat berkorelasi dengan tingkat pembayaran, dan ketidakpuasan dalam pembayaran adalah salah satu penyebab tersering dari turnover karyawan. ${ }^{19}$

Karyawan membutuhkan hubungan kerja yang timbal balik dengan perusahaan. Keamanan kerja harus diperhatikan untuk memelihara hubungan agar karyawan percaya bahwa usaha mereka akan dihargai. Di sisi lain, ketidakamanan kerja mengakibatkan hubungan kontrak yang lebih formal tetapi dengan hubungan timbal balik yang rendah. Tidak mengherankan jika ancaman pemutusan hubungan kerja (PHK) merupakan salah satu pukulan terbesar bagi loyalitas karyawan. ${ }^{18}$

Komitmen afektif adalah identifikasi secara perorangan terhadap organisasi. Jadi, masuk akal jika pemahaman organisasi akan menguat ketika karyawan memiliki pemahaman yang kuat tentang perusahaan. Karyawan secara rutin harus diberikan informasi mengenai kegiatan perusahaan dan pengalaman pribadi dari bagian lain. ${ }^{18}$

Karyawan merasa menjadi bagian organisasi ketika mereka berpartisipasi dalam pengambilan keputusan yang menyangkut masa depan perusahaan. Melalui keterlibatan karyawan, karyawan mulai melihat perusahaan sebagai refleksi dari keputusan mereka. Keterlibatan karyawan juga membangun loyalitas karena dengan menyertakan karyawan dalam pengambilan keputusan berarti perusahaan memercayai karyawannya. ${ }^{18}$

Kepercayaan berarti keyakinan kepada seseorang atau kelompok. Kepercayaan juga merupakan sebuah aktivitas timbal balik. Untuk memperoleh kepercayaan, pemimpin harus menunjukkan kepercayaan. Kepercayaan penting untuk komitmen organisasi karena menyentuh jantung dari hubungan kerja. Karyawan merasa wajib bekerja untuk perusahaan hanya ketika mereka mempercayai pemimpin mereka. ${ }^{18}$

Untuk mencegah tingginya turnover karyawan, perusahaan perlu meningkatkan komitmen organisasi karyawannya melalui beberapa cara, yaitu meningkatkan partisipasi karyawan dalam pengambilan keputusan, 
mengembangkan sistem kompensasi yang adil, merumuskan kebutuhan dan harapan pegawai ke dalam tujuan organisasi, menciptakan perilaku kepemimpinan yang berorientasi pada hubungan dan tugas, serta meningkatkan kejelasan peran karyawan dalam organisasi.

Salah satu cara yang dapat digunakan sebagai upaya untuk menurunkan angka turnover karyawan adalah dengan meningkatkan partisipasi karyawan dalam pengambilan keputusan. Partisipasi karyawan dalam pengambilan keputusan dapat menyebabkan timbulnya beberapa faktor yang memengaruhi komitmen organisasi sehingga dapat menumbuhkan loyalitas dalam diri karyawan yang akan berujung pada penurunan angka turnover. Faktor faktor yang memengaruhi komitmen organisasi, yang dapat timbul melalui peningkatan partisipasi karyawan dalam pengambilan keputusan, adalah keterlibatan karyawan dan perasaan dianggap penting oleh organisasi.

Karyawan dapat terlibat atau berpartisipasi secara langsung maupun tidak langsung dalam pengambilan keputusan. Mereka juga memiliki kesempatan untuk memengaruhi keputusan dalam berbagai tingkat organisasi. Karyawan yang terlibat secara langsung dalam pengambilan keputusan akan lebih baik dalam menjalankan hasil keputusan. Keterlibatan karyawan dapat menjadi hal yang penting dalam pengambilan keputusan karena pengetahuan karyawan merupakan keunggulan kompetitif bagi perusahaan. Karyawan kadang-kadang memiliki pengetahuan yang lebih banyak tentang pekerjaan mereka dibandingkan para manajer sehingga keputusan yang dibuat bersama para karyawan akan memberikan hasil yang lebih baik karena merupakan gabungan informasi yang lebih lengkap. ${ }^{20}$ Dengan demikian, makin tinggi keterlibatan karyawan, makin tinggi pula komitmen organisasi dan makin rendah angka turnover karyawan.

Partisipasi dalam pengambilan keputusan merupakan suatu penerapan manajemen sumber daya manusia yang memberikan tanda kepada karyawan bahwa mereka dihargai atau dianggap penting oleh perusahaan. Partisipasi dalam pengambilan keputusan juga dapat meningkatkan moral para karyawan, karena mereka mempersepsikan bahwa melalui partisipasi berarti perusahaan memandang karyawan sebagai rekan yang berharga dan berkompeten. Selain itu, partisipasi karyawan dalam pengambilan keputusan dapat mengurangi outcome negatif politik organisasi, yaitu meningkatnya stres kerja, ketidakpuasan kerja, kinerja yang rendah, dan menurunnya komitmen organisasi. Cara ini dapat mencegah peningkatan angka turnover karyawan. ${ }^{6}$

Cara kedua yang dapat digunakan sebagai upaya untuk menurunkan angka turnover karyawan adalah dengan mengembangkan sistem kompensasi yang adil. Cara ini dapat menumbuhkan loyalitas karyawan kepada perusahaan melalui timbulnya persepsi positif terhadap gaji serta rasa keadilan dan kepuasan kerja.

Persepsi seseorang dipengaruhi oleh kebutuhan, pengalaman, suasana emosional, kesiapan mental, dan latar belakang budaya. Faktor-faktor yang memengaruhi persepsi tersebut mengakibatkan persepsi seseorang terhadap hal yang sama dapat berbeda-beda. Persepsi karyawan terhadap keadilan kompensasi yang diterimanya juga dapat berbeda-beda. Apabila karyawan mempunyai persepsi yang positif terhadap kompensasi dari perusahaan, yaitu bila kompensasi dianggap adil karyawan akan lebih merasa puas dalam bekerja sehingga motivasi dan produktivitas atau kinerja karyawan akan meningkat. ${ }^{21}$ Jadi, apabila kompensasi diberikan secara adil dan layak dapat menyebabkan karyawan memiliki persepsi yang positif terhadap kompensasi, akan menyebabkan peningkatan komitmen organisasi dan penurunan angka turnover karyawan.

Keadilan dalam pemberian kompensasi ada dua macam, yaitu keadilan internal dan keadilan eksternal. Keadilan internal merupakan perbandingan antara hasil yang diperoleh dengan usaha yang telah dilakukan untuk memperoleh hasil tersebut. Keadilan internal mencakup apakah kompensasi yang diterima karyawan sudah sesuai dengan input yang diberikan oleh karyawan, yaitu pengalaman, kinerja atau produktivitas, masa kerja, waktu, tenaga, tingkat pendidikan, dan keahlian khusus. Keadilan eksternal merupakan perbandingan hasil yang diperoleh karyawan lain yang memiliki kualifikasi dan tugas yang sama. Keadilan eksternal mencakup apakah kompensasi yang diterima karyawan sama atau setidaknya sesuai dengan kompensasi yang diterima oleh karyawan lain yang mempunyai kualifikasi dan tugas yang sama dalam suatu perusahaan atau dalam pasar tenaga kerja eksternal.

Karyawan cenderung menginginkan sistem kompensasi yang adil sesuai harapan dan kontribusi mereka pada perusahaan. Kompensasi yang diterima bila dipersepsikan adil sesuai dengan harapan, tingkat penggajian, dan keterampilan karyawan akan menimbulkan kepuasan kerja, yang selanjutnya akan menyebabkan peningkatan loyalitas karyawan dan penurunan angka turnover karyawan. ${ }^{22}$

Cara ketiga yang dapat digunakan sebagai upaya untuk menurunkan angka turnover karyawan adalah dengan merumuskan kebutuhan dan harapan pegawai ke dalam tujuan organisasi. Cara ini dapat menyebabkan timbulnya beberapa faktor yang memengaruhi komitmen organisasi sehingga dapat menumbuhkan adanya loyalitas dalam diri karyawan yang akan berujung pada penurunan angka turnover. Faktor-faktor yang memengaruhi komitmen organisasi, yang dapat timbul melalui perumusan kebutuhan dan harapan pegawai ke dalam tujuan organisasi, adalah kepercayaan karyawan, keandalan organisasi, dan realisasi harapan. 
Penerimaan dan kepercayaan pegawai yang kuat terhadap nilai-nilai dan tujuan organisasi dapat ditumbuhkan dengan turut dirumuskannya kebutuhan dan harapan-harapan pegawai ke dalam tujuan organisasi agar terdapat kesesuaian antara nilai dan tujuan organisasi dengan nilai dan tujuan pegawai. Dengan cara ini, pegawai dengan rela akan berusaha mencapai tujuan organisasi karena secara tidak langsung kebutuhan dan tujuan pribadinya akan tercapai pula. ${ }^{12}$ Identifikasi nilai-nilai dan tujuan organisasi itu merupakan salah satu aspek komitmen organisasi. Makin tinggi identifikasi karyawan terhadap nilai-nilai dan tujuan organisasi, makin tinggi pula komitmen organisasi dan makin rendah angka turnover karyawan.

Jika organisasi dianggap dapat diandalkan dan peduli pada minat dan harapan anggota, yang berarti harapan anggota turut dirumuskan dalam tujuan organisasi, individu akan merasa lebih bertanggung jawab dan ingin membalas jasa organisasi. Hal ini akan meningkatkan loyalitas karyawan dan penurunan angka turnover karyawan. ${ }^{12}$

Karyawan juga akan memiliki anggapan atau keyakinan yang pasti akan realisasi harapannya dalam organisasi, seperti adanya penghargaan, pengakuan, promosi jabatan, partisipasi, rasa kebanggaan, dan kebersamaan dalam mewujudkan cita-cita dan tujuan organisasi. Dengan harapan dan keyakinan ini, karyawan akan memiliki komitmen yang tinggi pada organisasi. ${ }^{12}$

Cara keempat yang dapat digunakan sebagai upaya untuk menurunkan angka turnover karyawan adalah dengan menciptakan perilaku kepemimpinan yang berorientasi pada hubungan dan tugas. Perilaku demikian dapat menimbulkan faktor yang memengaruhi komitmen organisasi sehingga dapat menumbuhkan adanya loyalitas dalam diri karyawan yang akan berujung pada penurunan angka turnover. Faktor yang memengaruhi komitmen organisasi, yang dapat timbul melalui perilaku kepemimpinan yang berorientasi pada hubungan dan tugas, adalah persepsi positif terhadap perilaku atasan.

Pengaruh perilaku kepemimpinan yang berorientasi pada hubungan dan tugas terhadap komitmen organisasi telah diteliti. Berdasakan penelitian sebelumnya ditemukan bahwa perilaku kepemimpinan yang berorientasi pada hubungan, yang meliputi membangun kepercayaan, memberikan inspirasi, visi, mendorong kreativitas dan menekankan pengembangan, berpengaruh secara positif pada komitmen afektif karyawan. Sementara, perilaku kepemimpinan yang berorientasi pada tugas juga berpengaruh terhadap komitmen afektif karyawan, meski tingkat pengaruhnya lebih rendah. ${ }^{23}$

Cara kelima yang dapat digunakan sebagai upaya untuk menurunkan angka turnover karyawan adalah dengan meningkatkan kejelasan peran karyawan dalam organisasi, sebab adanya kejelasan peran karyawan dalam organisasi dapat menyebabkan timbulnya faktor yang memengaruhi komitmen organisasi sehingga dapat menumbuhkan adanya loyalitas dalam diri karyawan yang nantinya akan berujung pada penurunan angka turnover. Penyebab munculnya ambiguitas (ketidakjelasan) peran adalah komunikasi yang buruk antara karyawan dengan atasan dalam organisasi. ${ }^{24}$

Kejelasan peran didefinisikan sebagai suatu tingkat ketika seseorang karyawan dapat memastikan dan mengetahui dengan pasti bagaimana ia diharapkan oleh perusahaan dalam melakukan pekerjaan. Indikator kejelasan peran adalah meliputi pekerjaan yang jelas dan direncanakan, mengetahui tanggung jawabnya, mengetahui apa yang diharapkan perusahaan, kewenangan yang dimiliki, dan mengetahui apa yang harus dilakukan. Karyawan yang tidak memperoleh kejelasan peran tentang dukungan dan apa yang menjadi permintaan perusahaan maka akan merasakan kegelisahan dan ketegangan kerja yang besar yang berakibat pada kepuasan kerja. Dalam penelitian lain, disebutkan bahwa kejelasan peran akan berpengaruh positif terhadap minat bekerja, kesempatan untuk promosi, keseluruhan kepuasan kerja dan akan berpengaruh negatif terhadap ketegangan kerja dan pada kemungkinan untuk berhenti kerja. ${ }^{25}$

\section{Kesimpulan}

Salah satu permasalahan dalam kerja yang sering dikaitkan dengan rendahnya komitmen organisasi adalah pindah kerja (turnover). Turnover memiliki dampak yang merugikan bagi organisasi karena dapat menghambat efektivitas dan efisiensi kerja yang selanjutnya akan menurunkan tingkat produktivitas organisasi. Untuk mencegah tingginya turnover tersebut, perusahaan perlu memelihara dan mengembangkan komitmen organisasi karyawannya agar tetap kuat. Upaya-upaya untuk meningkatkan komitmen organisasi karyawan tersebut dapat berupa peningkatan partisipasi karyawan dalam pengambilan keputusan, pengembangan sistem kompensasi yang adil, perumusan kebutuhan dan harapan pegawai ke dalam tujuan organisasi, penciptaan perilaku kepemimpinan yang berorientasi pada hubungan dan tugas serta meningkatkan kejelasan peran karyawan dalam organisasi.

\section{Daftar Pustaka}

1. Riyanto M. Faktor-faktor yang mempengaruhi keinginan karyawan berpindah kerja. Ragam Jurnal Pengembangan Humaniora [online]. 2008 [diakses tanggal 15 Januari 2014]; 8 (3): 115-21. Diunduh dalam: http://www.polines.ac.id/ragam/index_files/jurnalragam/paper_3\%20des\%202008.pdf.

2. Rokhmah BE, Riani AL. Keterkaitan antara komitmen afektif dengan intensi turnover pada karyawan bagian produksi di PT. Usman Jaya Mekar Magelang. Jurnal Ilmiah Teknik Industri [online]. 2005 [diakses tanggal 17 Desember 2014]; 4(2): 78-85. Diunduh dalam: http://mgtofsdm.- 
files.wordpress.com/2012/09/keterkaitan-antara-komitmen-afektifdengan-intensi-turnover. pdf.

3. Nisa HDW, Suharsono Y, Ingarianti TM. Hubungan antara iklim organisasi dengan intensi turnover pada karyawan. Prosiding Seminar Nasional Universitas Muhammadiyah Malang. 2012; 74-94 [diakses tanggal 17 Desember 2014]. Diunduh dalam: http://eprints.umk.ac.id/ 499/14/Full\%2BProsiding\%2BSemnas\%2BPsi\%2BUMK\%2B2012.cr acked.83-103.pdf.

4. Gillies D. Manajemen keperawatan: suatu pendekatan sistem. Edisi ke3. Philadelphia: WB Saunder Company; 1994

5. Indriantoro N, Suwandi. Pengujian model turnover intention pada akuntan publik. Jurnal Riset Akuntansi Universitas Gajah Mada [online]. 2004 [diakses tanggal 15 Desember 2013]. Diunduh dalam: http://www.share-pdf.com/44dce65cf0c04818961bbe798e50ee07/3187_Skripsi\%20Allan\%20Fernando\%20Risambessy\%20_2004210212.pdf.

6. Kuean WL, Khin EWS, Kaur S. Employees' turnover intention to leave the Malaysian contexts. The South East Asian Journal of Management [serial on internet]. 2010 [cited 2013 Jan 5]; 4(2): 93-110. Available from: http://e-journal.uajy.ac.id/2634/6/5EM16565.pdf.

7. Victor J. Calculation methods for employee turnover [online]. Available from: http://www.ehow.com/info_ 8384981_calculation-methods-employee-turnover.html.

8. Sopiah. Perilaku organisasional. Yogyakarta: Penerbit Andi; 2008.

9. Greenberg J, Baron RA. Behaviour in organizations. 8th ed. New Jersey: Prentice Hall; 2003.

10. Greenberg J, Baron RA. Behaviour in organizations. 9th ed. New Jersey: Pearson International; 2008.

11. Steers RM, Porter L. Motivation and work behavior. 3rd ed. New York: McGraw Hill Book Company; 1983.

12. Kuntjoro ZS. Komitmen organisasi [e-psikologi]. 2002 [Diakses tanggal 15 Desember 2013]. Diunduh dalam: http://share.pdfonline.com/15be06a98314451eb6b96e7610a3893a/SKRIPSI_SITA_RESMI.htm.

13. Ramachandran VS. Encyclopedia of human behavior. 2nd ed. London: Academic Press is an imprint of Elsevier, Inc; 2012.

14. Cascio WF. Applied psychology in personnel management. 4th ed. New Jersey: Prentice Hall; 1991.

15. Peeters MCW, Jonge J, Taris TW. An introduction to contemporary work psychology. 1st ed. West Sussex: John Wiley \& Sons; 2014.

16. Noviarini NM, Saroyeni P. Peran locus of control dalam hubungan job insecurity dengan komitmen organisasi dan kepuasan kerja. Studi
Kasus: Karyawan PLN Denpasar [tesis]. Denpasar: Universitas Udayana; 2013.

17. Dyne L, Graham JW, Dienesch RM. Organizational citizenship behavior; construct redefinition, measurement and validation. Academy of Management Journal [serial on internet]. 1994 [cited 2013 Dec 13]; 37(4): 765-802. Available from: http://www.pustaka.ut.ac.id /dev25/pdftesis2/41072.pdf.

18. McShane S, Glinow M. Organizational behavior. United States: McGraw-Hill Co; 2000.

19. Mejia LRG, Balkin D, Cardy R. Managing human resources. 7th ed. New Jersey: Pearson Education; 2012.

20. Elele J, Field D. Participative decision making and organizational commitment comparing Nigerian and American employees. Cross Cultural Management: An International Journal [serial on internet]. 2010;17(4): 368-92. Available from: http://e-journal.uajy.ac.id/2634/6/5EM16565.pdf.

21. Cahyadi WA. Hubungan antara persepsi terhadap keadilan kompensasi dengan kepuasan kerja karyawan PT. Enseval Putera Megatrading Tbk. Cabang Semarang [skripsi]. Semarang: Universitas Diponegoro; 2007.

22. Wuryanto DA, Suharnomo. Analisis pengaruh promosi jabatan, persepsi keadilan kompensasi dan lingkungan kerja fisik terhadap kepuasan kerja karyawan. Jurnal Business Review Manajemen Fakultas Ekonomika dan Bisnis Universitas Diponegoro [online]. 2012 [diakses tanggal 15 Desember 2013]; 1(1): 1-12. Diunduh dalam: http://eprints.undip.ac.id/35790/1/jurnal_Danu_Adi_Wuryanto.pdf.

23. Suhana. Relationship analysis of leadership style, HRM practices, organizational culture, commitment, and performance. Study in People Crediting Bank (BPR) in Central Java. Usahawan [online]. 2007 [diakses tanggal 13 Desember 2014]; 36(10): 47-53. Diunduh dalam: http://journal.wima.ac.id/index.php/JUMMA/article/view/383/357.

24. Bhakti SJW. Pengaruh kepuasan kerja, komitmen organisasi, konflik peran, dan ambiguitas peran terhadap turnover intention. Studi Empiris pada Kantor Akuntan Publik di Semarang [skripsi]. Semarang: Universitas Katolik Soegijapranata; 2005.

25. Nahusona, Hilda CF, Rahardjo M, Raharja ST. Analisis faktor-faktor yang berpengaruh terhadap keinginan karyawan untuk pindah. Studi Kasus pada PT Bank Papua. Jurnal Studi Manajemen dan Organisasi [online]. 2004 [diakses tanggal 17 Januari 2014];1(2). Diunduh dalam: http://www.polines.ac.id/ragam/index_files/jurnalragam/paper_3\%20des\%202008.pdf. 